\title{
Determinants of Expenditure Decentralization: Evidence from China
}

\author{
ALFRED M. WU \\ The Hong Kong Institute of Education, Hong Kong, PR China \\ wumuluan@gmail.com \\ and \\ WEN WANG* \\ Indiana University-Purdue University Indianapolis, Indianapolis, USA \\ wenwang@gmail.com
}

To cite this article:

Wu, Alfred M., and Wen Wang. 2013. Determinants of expenditure decentralization: Evidence from China. World Development 46: 176-84.

To link to this article:

http://dx.doi.org/10.1016/j.worlddev.2013.02.004

Acknowledgment:

The authors are indebted to Dr. Long Liu for his help on econometrics and to Zhirong (Jerry) Zhao, Emerson Niou, Jing Vivian Zhan, Guang Zhang, Kang Chen, Shoukun Wang, Pan Suk Kim, Xi Wang and Lixing Li for helpful comments on an earlier version of this paper. The authors also benefited from helpful comments from the three anonymous referees. The BOCD (Barometer on China's Development) project at the Chinese University of Hong Kong provided access to sub-provincial data in China. 


\begin{abstract}
This study is the first attempt to examine the determinants of expenditure decentralization at sub-provincial levels in China. The Chinese central government gives detailed guidelines to local governments on public finance, but, ironically, their expenditure assignment is far from being well-regulated. Differences in fiscal decentralization on the expenditure side are enormous among local governments. Employing a panel dataset of 1995-2006, we provide empirical evidence that transfer dependency negatively affects expenditure decentralization in Chinese local governments. It suggests that intermediate governments, i.e. provincial governments, may have "grabbed" central grants for self-interests.
\end{abstract}

Keywords: decentralization, local government, intergovernmental relations, fiscal transfers, China 


\section{Determinants of Expenditure Decentralization: Evidence from China}

\section{INTRODUCTION}

This paper aims to explore the determinants of expenditure decentralization in China, the world's third largest country by total land area, and to examine their broad policy implications. Though China is a constitutionally unitary country, fiscal decentralization at sub-provincial levels varies tremendously across provinces, especially on the expenditure side. While there is a growing literature on the factors that explain the extent of fiscal decentralization, we still know little about what drives fiscal decentralization in different places (Bodman \& Hodge, 2010). Taking advantage of the substantial variation in sub-provincial expenditure decentralization in China, this study contributes to this body of literature by testing hypotheses concerning some potential determinants of fiscal decentralization reported in the literature.

Investigating the drivers of fiscal decentralization should be meaningful as most studies evaluate the effects of fiscal decentralization without looking into its complexities. Without an in-depth understanding of fiscal decentralization per se, it often runs the risk of overshooting when making conclusions about the benefits or perils of decentralization.

Decentralization is "often viewed as a shift of authority towards local governments 
and away from central governments, with total government authority over society and economy imagined as fixed" (Rodden, 2004, p. 482). Fiscal decentralization, more often than not, referring to the shift of fiscal responsibilities to lower levels of government, is fundamental to public governance in reality. Studies on fiscal decentralization have been burgeoning in the international community; however, the drivers of fiscal decentralization have remained little known thus far. Early literature on fiscal decentralization focuses on power assignment in the public sector (Tiebout, 1956; Oates, 2005). The bulk of the literature in recent decades has investigated the impact of fiscal decentralization on public governance (Prud'homme, 1995; Rodden \& Wibbels, 2002; Uchimura \& Jütting, 2009). The drivers of decentralization have been largely overlooked, except for some recent efforts such as Bodman and Hodge (2010) and Panizza (1999). Compared with studies on the impacts of fiscal decentralization, untangling factors underpinning fiscal decentralization will be instrumental in generating a better understanding of the complexity and dynamics of decentralization in different politico-economic backgrounds. In many cases, fiscal decentralization per se is not the problem, but decentralization may have been implemented in an incompatible environment. When the drivers of decentralization/centralization are discovered, the evaluation of decentralization/centralization will be more pointed and the nuanced side of 
central-local relationship will be more revealing.

This study will investigate the regional variation of fiscal decentralization,

specifically on the expenditure side, in China. Fiscal decentralization at sub-provincial levels in China is seriously under-explored in the literature. Though the literature on the impact of fiscal decentralization on economic development and public governance has burgeoned in recent years (for example Uchimura \& Jütting, 2009), the investigation into the determinants of fiscal decentralization is rare. As the geographic areas of many Chinese provinces are equal to those of European countries, diversities between provinces in political, economic and social aspects are astonishingly large. Sub-provincial decentralization in China is much more diversified than that in many other countries (Dollar \& Hofman, 2008). Exploring fiscal decentralization, Chinese style, therefore, will potentially generate broad implications for other countries.

The Chinese central government does not exert a tight control over sub-provincial expenditure decentralization. Provincial governments in China enjoy substantial discretion in this regard. According to the Constitution of the People's Republic of China (PRC) and the China Statistical Yearbook (2009), subnational governments 
refer to 31 provincial governments, 333 prefectural governments, 2,859 county

governments, and 40,828 township governments (sub-provincial governments include prefectural, county and township governments). Local governments provide the bulk of public services in China wherein 70 percent of public money has been spent at the subnational level with more than 55 percent being spent by sub-provincial governments (World Bank, 2002). Due to the efforts to build a service-oriented government in recent years, local governments will take up more responsibilities for the provision of public services over time in China. Expenditure assignment for local governments is nonetheless far from being well-regulated (see also Martinez-Vazquez \& Qiao, 2011). The State Council (2002), the top administrative body of the central government in China, provides regulations on local fiscal decentralization, paying most attention to the revenue side of fiscal decentralization while the regulations on the expenditure side have been nearly left blank. Variations in fiscal decentralization on the expenditure side are enormous across localities in China. For example, sub-provincial governments spent 85.32 percent of public money in Guangdong Province while only 53.72 percent was expended in Qinghai Province between 1995 and 2006 (see The Compendium of Fiscal Statistics for All Prefectures, Cities, and Counties, 1996-2007). Thus we pose our research question for this analysis: What drives the variation in sub-provincial expenditure decentralization in China? Based on 
the empirical results of our analysis, we attempt to draw policy implications for the improvement of the intergovernmental fiscal system in China.

In general, our empirical analysis confirms a negative relationship between transfer dependency (central transfer as a share of local expenditure) and fiscal decentralization in the Chinese context. Regions with a greater transfer-dependency tend to have a higher centralization of expenditure within provinces, ceteris paribus. As observers have long suspected that local governments play fiscal games with national governments in order to gain more grants in some countries (Gimpelson \& Treisman, 2002), the results of our analysis also suggest a predatory role played by local governments in China. In addition, our study provides suggestive evidence that both population density and foreign direct investment (FDI) have negative influences over expenditure decentralization while economic development adds almost nothing to the explanatory power of our models for expenditure decentralization.

The remainder of the article is organized as follows: Section 2 discusses the theories and empirical evidence of the potential determinants of fiscal decentralization with an emphasis on the relationship between transfer dependency and expenditure decentralization. Section 3 presents data, model specification and estimation 
methodology. Section 4 provides the empirical results of our analysis while section 5

offers a discussion of them. Section 6 concludes.

\section{POTENTIAL CAUSES OF FISCAL DECENTRALIZATION}

Here we summarize the factors that have been used to explain fiscal decentralization in the literature, much of which is drawn from cross-national evidence. These potential determinants of fiscal decentralization identified in the literature are employed as the basis of our theoretical framework for this study.

\subsection{Explaining the tie between transfer dependency and fiscal decentralization}

The effects of fiscal transfers from the federal government (or the central government in countries like China) to local governments on local spending have been investigated extensively (for example the flypaper effect; see Bailey and Connolly (1998)). Nevertheless, the majority of the literature is linked with the theories and hypotheses (such as the median voter hypothesis) developed against a context of electoral politics. The impact of transfers from higher authorities on fiscal decentralization remains largely underexplored.

In some countries, the national government cannot channel grants to grassroots 
governments but have to go through intermediate governments according to the Constitutions (Hernández-Trillo \& Jarillo-Rabling, 2008). Though it is not the case in China institutionally, the Chinese government has adopted a de facto system in practice. That is, central grants have to go through provincial governments before reaching prefectural and county governments. There is a risk that provincial governments may retain the intergovernmental transfers for their self-interests. Thus, the relationship between transfer dependency and expenditure decentralization could be either negative or positive, depending on the role and function of intermediate governments who are responsible for transmitting central grants to local governments.

Provincial governments in China, according to the State Council (2002), should hold back their own spending and augment central transfers to sub-provincial governments. It means that provincial governments are obligated to not only pass on central transfers to sub-provincial governments but also relinquish some parts of their own financial resources to lower levels of government as the latter provides the bulk of public services to citizens. In reality, no evidence suggests that provincial governments channel much of their own resources (in addition to transfers from the central government) to sub-provincial governments. The World Bank (2007) aptly points out that it "appears to be that a typical province makes little, if any, 
contribution to intergovernmental transfers to lower levels that are designed to

equalize fiscal capacities" (p.53). Worse still, evidence here and elsewhere suggests that provincial governments may capture some central transfers, which are supposed to be used to fund local projects and the provision of public services. Therefore, we should pay great attention to the role of provincial governments in the intergovernmental transfer system.

The hypothesis about a negative relationship between transfer dependency and fiscal decentralization has been confirmed in a study using the case of Russia. Freinkman and Plekhanov (2009) find that those transfer-dependent regions tend to have greater fiscal centralization, other things being equal. As central grants flow through regional governments, it would be possible for them to spend the transfers rather than distribute them to lower-level governments. ${ }^{1}$ When controlling for all other regional characteristics, higher transfer dependency is found to be associated with lower fiscal decentralization.

Cross-national evidence, however, suggests that a greater amount of fiscal transfers tend to encourage more local expenditure as soft budget constraints arise (Bodman \& Hodge, 2010; Letelier S., 2005). ${ }^{2}$ Higher transfer dependency thus is associated with 
greater fiscal decentralization. Another line of inference also supports the positive relationship between transfer dependency and fiscal decentralization. As intergovernmental transfers partially serve to compensate local governments for their implementation of central mandates, swelling transfers to local governments mean that local governments bear more responsibility for spending; thereby the share of local spending increases consequently. In sum, the positive relationship between transfer dependency and fiscal decentralization has been established by several cross-national studies for developed countries (Kee, 1977; Letelier S., 2005).

\subsection{Other drivers of fiscal decentralization}

In addition to the main hypothesis discussed above, we examine the following factors that affect the levels of fiscal decentralization.

Economic development. There are two contrasting arguments related to the role of economic development on fiscal decentralization. One the one hand, economic development is expected to be positively related to fiscal decentralization. The majority of basic public services are provided by local governments in countries like China. Some argue that expenditure at the local level will increase as the provision of basic public goods will be expensive when wealthier citizens demand diversified and 
more expensive public services (Martinez-Vazquez \& McNab, 2003; Tanzi, 2000;

Wheare, 1964). On the other hand, economic development may be negatively related to fiscal decentralization. As suggested by Letelier S. (2005), an increasing emphasis will be given to income redistribution when a locality or country becomes more affluent; consequently, more central coordination and central investment will be demanded gradually. Expenditure by higher authorities may thus grow faster than that at the local level.

Empirical evidence for the effect of economic development on fiscal decentralization is mixed. Early studies on this issue find that per capita income of a given country is significantly and positively related to fiscal decentralization (Kee, 1977; Panizza, 1999). Recent research has found some new evidence on the different effects of economic development in developed and developing economies (Bodman \& Hodge, 2010; Letelier S., 2005), namely a positive relationship in high-income countries and a negative one in low-income countries.

Population size and population density. Litvack and Oates (1971) suggest that social congestion will increase when population size grows. Provided that local governments offer the majority of public services to citizens, the rising cost of 
congestion will increase the share of local expenditure in total government spending (Bodman \& Hodge, 2010). A higher population density is also likely to be associated with lower cost of public services due to increasing returns to scale in the provision of public services. A lower population density increases the cost of public services provided that other conditions remain constant.

Previous studies generally indicate a positive relationship between population size and fiscal decentralization, and a negative one between population density and fiscal decentralization (Bodman \& Hodge, 2010; Cerniglia, 2003; Freinkman \& Plekhanov, 2005). Therefore, we expect a larger population size and a lower density to be associated with a higher fiscal decentralization in local China.

Openness to trade and foreign direct investment (FDI). Compared with the factors of income and population size, both openness to trade and FDI garner much less attention in the literature. Kimakova (2009) and Rodrik (1998) argue that a trade-oriented economy is vulnerable to outside economic shocks; thus the economic coordination by the central government becomes imperative in an open economy. Integration into the international market thus improves fiscal centralization, all other things being held constant (Garrett \& Rodden, 2003; Stegarescu, 2009). 
The relationship between trade openness and fiscal decentralization has been tested largely with cross-national datasets. Given the fact that FDI represents the openness of an economy, what would be the impact of both trade and economic openness on fiscal decentralization in a domestic circumstance? A burgeoning scholarship confirms that both trade openness and FDI can serve as a device to improve good governance (see Malesky, 2004; Wu \& Lin, 2012). Foreigners, especially those from developed countries purchasing goods or investing in developing countries, may push recipient governments to improve their public services or "leak" some practical hints on good public governance to destinations of trade and investment. As decentralized governance has been embraced as an effective instrument to improve public governance in many industrialized countries, our assumption is that both openness to trade and FDI may enhance the level of fiscal decentralization in developing countries like China through policy imitation and diffusion. We thus hypothesize that both openness to trade and FDI have positive impacts on fiscal decentralization in local China.

\section{DATA, MODEL SPECIFICATION AND ESTIMATION METHODOLOGY}

We conduct our empirical analysis using a panel dataset from 30 provinces in China between 1995 and 2006 (Tibet is excluded due to data unavailability). Data used for 
this analysis were taken from the Compendium of Fiscal Statistics for All Prefectures,

Cities, and Counties (Quanguo dishixian caizheng tongji ziliao), the Finance

Yearbook of China (zhongguo caizheng nianjian), and China Compendium of

Statistics in 1949-2008.

\section{Definition of variables}

Based on the literature reviewed in the previous section, we specify our empirical

models, including the dependent variable and independent variables, for this analysis.

\section{Dependent variable}

The dependent variable, fiscal decentralization, is measured as sub-provincial expenditure as the share of total provincial and sub-provincial expenditure. This means that prefectural, county and township public expenditure is summed up, and then the number is divided by total provincial and sub-provincial government spending in a given province. Measuring fiscal decentralization is a formidable challenge that attracts the bulk of scholarly debate (see Yeung, 2009). Since fiscal decentralization is multidimensional, a single proxy can hardly capture the dynamics of power assignment across governments. ${ }^{3}$ Acknowledging the imperfection of measuring fiscal decentralization as expenditure shares, we nevertheless have some strong reasons to use sub-provincial fiscal decentralization as the dependent variable. 
First, the measurement of fiscal decentralization tends to be more problematic in cross-national studies because historical and legal backgrounds of public finance are very different among different countries (Stegarescu, 2005). The within-country comparison nonetheless can avoid this problem. Though the levels of expenditure decentralization vary across provinces and time periods in China, decentralization is generally governed by the same set of legal frameworks. Second, measurement errors of fiscal decentralization are more problematic in models with decentralization being used as an independent variable. Fiscal decentralization used as a dependent variable instead causes less concern (Stegarescu, 2005). ${ }^{4}$

We target the variation on the expenditure side and argue that expenditure share at the sub-provincial level can effectively represent fiscal decentralization in local China. As public spending represents the government's involvement in society, expenditure data are revealing in explaining variations in local governance; policy implications drawn on this therefore are intriguing. In addition, the revenue side of fiscal decentralization is also tested, though its empirical results are not reported in this study. Policy implications of revenue decentralization are unclear as local governments actually have not been assigned the authority to borrow and to determine their tax bases and tax rates in China. 


\section{Independent variable}

Transfer dependency refers to the extent to which provincial expenditure is funded by

central transfers. The numerator of the variable is central transfers to the provinces,

including those for provincial, prefectural, county and township levels of government,

while the denominator refers to spending by all of the four tiers of government within

a province in China. ${ }^{5}$ It is the amount of central transfers to all tiers within a province divided by the expenditure by all tiers within the province. Economic Development is measured as real GDP per capita at the provincial level, with 1992 being used as the base year. The real GDP per capita is calculated as the nominal GDP per capita divided by provincial GDP deflator (in natural logarithm). Population density is measured as the number of resident population (de facto residents, changzhu renkou) per square kilometer of land area in a given province (in natural logarithm). ${ }^{6}$ Openness to trade is measured as the share of imports plus exports (yuan) in provincial GDP. FDI denotes the volume of foreign direct investment (yuan) as a share of provincial GDP in a given province.

In addition, the industrial and economic structures in a province may potentially affect the patterns of local spending. In some models, we add SOE employment and 
economic structure as controls to improve the robustness of the empirical models.

SOE employment refers to the number of state-owned enterprise employees as a share of the total population. Economic structure is measured as the volume of the secondary sector in local GDP. Table 1 provides the measurement and data sources, and Table 2 presents the descriptive statistics of all of the variables used in this empirical analysis.

[Tables 1 and 2 about here]

\section{Estimation methodology}

Panel data models are often estimated with either fixed effects or random effects models. Random effects models make the assumption that the random effects are uncorrelated with the random error. If this assumption is wrong, the random effects estimator will be inconsistent (Greene, 2002). As random effects are a more efficient estimator than fixed effects, we should run random effects if it is statistically justifiable. However, the Hausman test statistic we obtain is highly significant, suggesting that a fixed effects model should be adopted.

To investigate the determinants of fiscal decentralization in China, first of all, we 
estimate the following linear fixed effects model:

$$
Y_{i t}={ }_{0}+X_{i t}+{ }_{i}+{ }_{t}+{ }_{i t}
$$

where $Y$ is our dependent variable, fiscal decentralization, that is equal to the share of sub-provincial expenditure in total subnational expenditure for province $i$ in year $t$. As discussed above, $X$ is a matrix of our major independent variables, including transfer dependency, economic development, population density, openness to trade and FDI. In the model, ${ }_{i}$ represents the province-fixed effects and ${ }_{t}$ the year-fixed effects, while is the random error. In addition, in order to control for the differences in economic and industrial structure in each province, we also estimate alternative models that include the two control variables - SOE employment and economic structure.

A major challenge needed to be dealt with in estimating the empirical model is the potential endogeneity of the economic development variable, indicated as real GDP per capita. As the dependent variable, fiscal decentralization, may have an impact on provincial economic development, ${ }^{7}$ the causality may be reciprocal in the model. If we ignore the problem in estimation, the coefficient estimates may be biased and inconsistent (Wooldridge, 2006). In order to deal with the empirical challenge, we also run two-stage least squares (2SLS) estimation, using one-year and two-year lags 
of real GDP per capita as instruments. An instrumental variable must have the following two properties: (1) it must be uncorrelated with the error term in the model; (2) it must be partially correlated with the endogenous independent variable. To use the lags of GDP as instruments, we assure that the time order of effect on the dependent variable is correct and that it is correlated with the GDP in the current period. We also use the Newey-West estimation procedure to deal with the problem of autocorrelation and heteroskedasticity. This procedure computes ordinary least squares (OLS) estimates with heteroskedasticity and autocorrelation consistent (HAC) standard errors (Newey \& West, 1987).

In addition, since our dependent variable, measured as the share of sub-provincial expenditure in total provincial expenditure, is necessarily bounded between zero and one, standard linear models may not provide an accurate picture of the impacts of some independent variables on fiscal decentralization throughout their entire distribution. Furthermore, such models do not ensure that the expected value falls between zero and one. In recent years, there has been an emerging empirical literature attempting to explain fractional responses (Papke and Wooldridge, 1996, 2008). Following the approach recently proposed for panel data in Papke and Wooldridge (2008), we use the method of pooled quasi-MLE (QMLE) to estimate a fractional 
probit model in the following form:

$$
E\left(Y_{i t} \mid x_{i 1}, x_{i 2}, \ldots, x_{i T}\right)=\left({ }_{t}+x_{i t}+\bar{x}_{i}\right)
$$

where is the cumulative distribution function (CDF) of a normal distribution, and the presence of $\quad$ indicates that we are allowing a different intercept in each year.

We provide estimates of the partial effects averaged across the population, or the "average partial effects" (APEs), which are computed based on the scaled coefficients.

The APEs are comparable to the linear model estimates. We use bootstrapping to obtain the bootstrap standard errors for the APEs. This approach allows for time-invariant unobserved effects that can be correlated with explanatory variables. The model is estimated assuming that the explanatory variables are strictly exogenous. We then relax the strict exogeneity assumption and treat the economic development variable as endogenous.

\section{EMPIRICAL RESULTS}

Table 3 presents the estimation results of four linear models and two fractional probit models. The four linear models include the baseline model with all the major independent variables, the model with the inclusion of two additional control variables and the two 2SLS models with economic development variable treated as endogenous. We also estimated two fractional probit models with and without the economic development variable being treated as endogenous. 
The baseline model (model 1) has an R-squared of 0.52 , indicating that 52 percent of the variation in the dependent variable is explained in the empirical model. The test statistics for heteroskedasticity and autocorrelation indicated their presence in the model, so we used the Newey-West estimation procedure to compute robust HAC standard errors. ${ }^{8}$ The coefficient of transfer dependency is statistically significant at the 5 percent level; a one percentage point increase in the ratio of central transfers to provincial expenditure lowers the share of sub-provincial expenditure in total expenditure by 0.164 percentage point. In other words, an average province with 50.69 percent in transfer dependency will have an 8.31 percentage point drop in expenditure decentralization, a substantial 11.82 percent drop from the average ratio of 70.63 percent. Economic development, or real GDP per capita, has a coefficient of 6.421, but it is not statistically significant at the 10 percent level. Population density is statistically significant at the 10 percent level, and a 1 percent increase in population density leads to a drop of 0.320 percentage point in the dependent variable. A one percentage point increase in the share of FDI in GDP is associated with a 0.279 percentage point drop in the dependent variable, and the coefficient is significant at the 5 percent level. The share of trade in GDP has a positive coefficient, but it is not statistically significant. 
In model 2, we added two control variables - the share of state-owned enterprise (SOE) employment in the total population and the share of secondary industry output in the total GDP. The inclusion of the two additional variables does not significantly change our empirical results.

In models 3 and 4, the economic development variable is treated as endogenous, ${ }^{9}$ and the results are similar to those in models 1 and 2, having no flip of sign in coefficient estimates or a substantial change in the level of significance. Comparing the results in models 2 and 4, the coefficient on transfer dependency changes from -0.156 to -0.169 . The coefficients of population density and share of FDI in GDP drop from - -0.316 and -0.270 to -0.230 and -0.203 , respectively. The coefficients of other variables are not statistically significant at the 10 percent level. ${ }^{10}$

The linear models reported above do not ensure that the expected value of the dependent variable lies on the unit interval. We used pooled QMLE to estimate two fractional probit models; one model (model 5) assumes that all explanatory variables are strictly exogenous, and the other (model 6) allows the economic development variable to be endogenous. In both models, we used 1,000 bootstrap replications to 
obtain bootstrap standard errors, which are robust to general heteroskedasticity and autocorrelation. The transfer dependency variable remains statistically highly significant in both models. Its APE estimates, -0.158 in model 5 and -0.159 in model 6 , are very similar in magnitude to the estimates of fixed effects and 2SLS models. So the three sets of estimates tell a consistent story: transfer dependency has a negative and statistically significant effect on fiscal decentralization.

[Table 3 about here]

\section{DISCUSSION}

Our empirical study on the sub-provincial variation of expenditure decentralization generates the following results. First, there is a significant negative relationship between transfer dependency and expenditure decentralization. Second, both population density and the share of FDI in GDP have a significant negative effect on fiscal decentralization, though they lose their statistical significance in the fractional probit models. Third, the estimated coefficients on economic development and openness to trade are not statistically significant.

The negative relationship between transfer dependency and expenditure decentralization suggests that intermediate governments-provincial governments-may have "grabbed" central grants for self-interests. As transfers serve to compensate local 
efforts in providing public services and reducing regional variations in fiscal capacity,

higher transfer dependency should be correlated with greater expenditure decentralization in China, other things being equal. It is, however, exactly the opposite in reality. We argue that the surprising fact indicates the existence of a grabbing hand of intermediate governments in China. We suspect that, in some regions, central grants may have been leaking and have not been used for the intended purposes. China is not alone in this case. As noted previously, Freinkman and Plekhanov (2009) find a similar problem with intermediate governments due to the distorted fiscal incentive structure in Russia, drawing on data between the late 1990s and early 2000s.

We need to pay attention to the role played by intermediate governments in the design of a well-functioning intergovernmental transfer system. Much scholarship in this area previously investigates the problem of grantors or recipient governments on intergovernmental transfers. Nevertheless, the role of intermediate governments in intergovernmental grants (flowing through them but not for them) receives scant attention in the literature.

In line with the level-by-level administration system (World Bank, 2007), the central 
grant in China goes through provincial governments before it reaches lower-level governments. ${ }^{11}$ Therefore, there is a risk that intermediate governments may retain the intergovernmental transfers for their self-interests. Our study suggests that, similar to some other developing countries, at least in transfer-dependent regions, provincial governments in China tend not to decentralize financial resources to grassroots governments though the latter needs substantial financial resources for public services.

A predatory role of provincial governments in China was reported by other studies as well. Based on their empirical research of fiscal equalization in China, Martinez-Vazquez et al. (2008) note that intermediate governments (provincial governments) play a de-equalizing role in closing the regional gap of fiscal capacity in China. Zhang (2009) documents that provincial governments in China retain some central grants inappropriately and prey on grassroots governments. Official accounts also suggest a predatory role of provincial governments in the Chinese intergovernmental system. The National Audit Office (2004) reported that only 22.5 percent of central transfers actually appeared in provincial budget books in 2003 though all transfers from higher authorities must have been included in the budget. As an explanation, Li Jinhua, the former Auditor-General of the Chinese central 
government, once offered an intriguing metaphor for the Chinese intergovernmental transfer system:

The intergovernmental transfer system in China is like a very long canal running from the central to the local governments. The canal is leaky, however $(\mathrm{Wu}, 2010$, p.159).

We try to gauge the reasons behind the role played by provincial governments. Parallel to Russia and other developing countries, the Chinese case demonstrates an intricate situation of fiscal games. Employing the data of Russia, Gimpelson and Treisman (2002) document fiscal games played by the national and sub-national governments wherein public employment and political patronage are key to understanding the distorted intergovernmental transfer system in Russia. On the one hand, local governments increased public employment beyond their own fiscal capacity for the purpose of asking for more central transfers. The national government, on the other hand, was willing to bail out some governments on the brink of public sector strikes related to pay arrears as politicians in Moscow fully understood the cost of strikes. 
In the case of China, the bulk of budgetary expenditure has been spent on public sector employment (Gong $\& W u, 2012)$. The centralization of expenditure in transfer-dependent regions in our study thus could probably be explained by bureaucratic expansion at the provincial level. Similar to other developing countries, transfer-dependent regions may rely on central transfers to expand their employees while the central government buys off these regions for political stability through substantial central transfers. Parallel to what happens in Russia, the situation in China calls local public governance into question.

\section{CONCLUSION}

The paper examines the determinants of fiscal decentralization and provides a snapshot of the dynamics of central transfers in China. The study complements Freinkman and Plekhanov's (2009) findings on fiscal decentralization that regions relying more on central transfers tend to have a more centralized fiscal system within the region. Instead of only reporting the findings, we offer a tentative explanation for the negative relationship between transfer dependency and expenditure decentralization in China. That is, some intermediate governments might use central transfers to enhance the growth of public employment for their own interests. This study also contributes to our understanding of subnational fiscal decentralization in 
developing economies. Drawing on data at the provincial, prefectural and county levels in China, it has generated empirical results that help to identify the determinants of China's expenditure decentralization, and probably for other developing countries as well.

The study suggests that an appropriate fiscal incentive structure for regional governments is needed. More importantly, an effective monitoring of intermediate governments is imperative especially in developing countries such as China. In the Western democracies, the strengthening of party leadership and the partisan link between the central and local governors may effectively prevent regional governments from preying on grassroots governments, despite some exceptions (Enikolopov \& Zhuravskaya, 2007; Riker, 1964). Alternatively, appropriate administrative organizations (independent commissions) for regulating the intergovernmental system prove to be instrumental in holding local governments accountable to the principal in many countries (Sato, 2007; Shah, 2007). In contrast to practices in the Western context, the Chinese government actually attempts to use its unique nomenclature system to make regional governors comply with central mandates (Huang, 1996). The personnel control system nonetheless is not always effective as local governments often find ways to circumvent central control in reality. Based on this study, we 
propose some preliminary measures to curb the predatory role of intermediate governments and improve the intergovernmental fiscal system in China.

First, transparency in the intergovernmental system must be strengthened. It is paramount for the establishment of an effective transfer system in a country. The central government should disclose the information on fiscal transfers to the public. ${ }^{12}$ The monitoring can also be strengthened by utilizing increasingly assertive congresses to exercise a check over intermediate governments. In a study of public accountability in Zhejiang Province in China, Hsu (2009) finds that local villages' congresses can exert an effective check on government budgetary behavior in these areas. We argue that through empowering local congresses, both transparency and fiscal discipline may be improved to some extent.

Second, the fiscal capacity of local governments must be enhanced. The World Bank (2007) argues that " $[u]$ nder conditions of fiscal stress, the temptation for higher levels to 'grab' revenues is undoubtedly great" (p.42). In recent years, accompanying the Chinese economic miracle has been an exceptionally swelling central coffer. The central government's rising fiscal capacity has not shown a strong trickle-down effect in local China, with subnational governments, especially county governments, striving 
hard to keep their heads above water (Guo, 2008). Improving fiscal capacity at the local level thus is imperative in China.

Third, the national government's role should change from being a provider to an enabler. The era of relying on the central government efforts to promote economic development has faded away. Local governments have been key players in promoting economic development around the world (Ebel \& Yilmaz, 2003). Recent years' public governance theory puts greater emphasis on the enabler role of the national government. However, the central government in China has acted as the provider of both decision-making and financial resources for decades, which leads to the waste and leakage of public money and quite often cases of corruption in reality. Gap-filling transfers - aiming to improve the local capacity of providing public services, ironically, often result in increasing expenditure centralization within provinces, rather than better public service provision in some localities. Therefore, it is time to change the central government's role from a financial provider to an enabler of a well-functioning intergovernmental system. 


\section{REFERENCES}

Bailey, S. J., \& Connolly, S. (1998). The flypaper effect: Identifying areas for further research. Public Choice, 95(3), 335-361.

Baum, C., Schaffer, M., \& Stillman, S. (2007). Enhanced routines for instrumental variables/GMM estimation and testing. Stata Journal, 7(4), 465-506.

Bodman, P., \& Hodge, A. (2010). What drives fiscal decentralisation? Further assessing the role of income. Fiscal Studies, 31(3), 373-404.

Cerniglia, F. (2003). Decentralization in the public sector: Quantitative aspects in federal and unitary countries. Journal of Policy Modeling, 25(8), 749-776.

Dollar, D., \& Hofman, B. (2008). Intergovernmental fiscal reforms, expenditure assignment, and governance. In J. Lou, \& S. Wang (Eds.), Public finance in China : Reform and growth for a harmonious society (pp. 39-51). Washington, D.C.: World Bank.

Ebel, R. D., \& Yilmaz, S. (2003). On the measurement and impact of fiscal decentralization. In J. Martinez-Vazquez, \& J. Alm (Eds.), Public finance in developing and transitional countries: Essays in honor of Richard Bird (pp. 101-119). Cheltenham, UK; Northampton, MA: Edward Elgar. 
Enikolopov, R., \& Zhuravskaya, E. (2007). Decentralization and political institutions. Journal of Public Economics, 91(11-12), 2261-2290.

Freinkman, L., \& Plekhanov, A. (2005). What determines the extent of fiscal decentralization? The Russian paradox No. Policy Research Working Paper 3710). Washington, D.C.: World Bank.

Freinkman, L., \& Plekhanov, A. (2009). Fiscal decentralization in rentier regions: Evidence from Russia. World Development, 37(2), 503-512.

Garrett, G., \& Rodden, J. (2003). Globalization and fiscal decentralization. In M. Kahler, \& D. A. Lake (Eds.), Governance in a global economy: Political authority in transition (pp. 87-109). Princeton, N.J.: Princeton University Press.

Gimpelson, V., \& Treisman, D. (2002). Fiscal games and public employment: A theory with evidence from Russia. World Politics, 54(2), 145-183.

Gong, T., \& Wu, A. M. (2012). Central Mandates in Flux: An Empirical Study of Local Noncompliance in China, Publius: The Journal of Federalism, 42(2), 313-333.

Greene, W. H. (2000). Econometric analysis (4th ed.). Upper Saddle River, N.J.: Prentice Hall. 
Greene, W. H. (2002). LIMDEP econometric modeling guide: Version 8.0. New York:

Econometric Software.

Guo, G. (2008). Vertical imbalance and local fiscal discipline in China. Journal of East Asian Studies, 8(1), 61-88.

Hayashi, F. (2000). Econometrics. Princeton, N.J.: Princeton University Press.

Hernández-Trillo, F., \& Jarillo-Rabling, B. (2008). Is local beautiful? Fiscal decentralization in Mexico. World Development, 36(9), 1547-1558.

Hsu, S. P. (2009). In search of public accountability: The 'Wenling model' in China. The Australian Journal of Public Administration, 68(s1), s40-s50.

Huang, Y. (1996). Central-local relations in China during the reform era: The economic and institutional dimensions. World Development, 24(4), 655-672.

Kee, W. S. (1977). Fiscal decentralization and economic development. Public Finance Review, 5(1), 79-79.

Kimakova, A. (2009). Government size and openness revisited: The case of financial globalization. Kyklos, 62(3), 394-406. 
Letelier S., L. (2005). Explaining fiscal decentralization. Public Finance Review, $33(2), 155-183$.

Lin, J. Y., \& Liu, Z. (2000). Fiscal decentralization and economic growth in China. Economic Development and Cultural Change, 49(1), 1-21.

Litvack, J., \& Oates, W. (1971). Group size and the output of public goods: Theory and application to state-local finance in the United States. Public Finance, 25(2), $42-58$.

Malesky, E. J. (2004). Push, pull, and reinforcing: The channels of FDI influence on provincial governance in Vietnam. In B. J. Kerkvliet, \& D. G. Marr (Eds.), Beyond Hanoi : Local government in Vietnam (pp. 285-333). Copenhagen: Nias.

Martinez-Vazquez, J., \& McNab, R. M. (2003). Fiscal decentralization and economic growth. World Development, 31(9), 1597-1616.

Martinez-Vazquez, J., \& Qiao, B. (2011). Assessing the assignment of expenditure responsibilities. In J. Y. Man \& Y. Hong, (Eds.), China's local public finance in transition (pp. 21-40). Cambridge, Mass.: Lincoln Institute of Land Policy.

Martinez-Vazquez, J., Qiao, B., \& Zhang, L. (2008). The role of provincial policies in fiscal equalization outcomes in China. China Review, 8(2), 135-167. 
Mogues, T., \& Benin, S. Do external grants to district governments discourage own revenue generation? A look at local public finance dynamics in Ghana. World Development (2012), 40(5), 1054-1067.

National Audit Office. (2004). The audit report on central government budget and other financial issues. http://www.audit.gov.cn/n1992130/n1992165/n2032598/n2376391/2376652.html

Newey, W. K. and K. D. West, 1987. A Simple, Positive Semi-definite, Heteroskedasticity and Autocorrelation Consistent Covariance Matrix. Econometrica, 55 (3): 703-708.

Oates, W. E. (2005). Toward A second-generation theory of fiscal federalism. International Tax and Public Finance, 12(4), 349-373.

Panizza, U. (1999). On the determinants of fiscal centralization: Theory and evidence. Journal of Public Economics, 74(1), 97-139.

Papke, L. E., \& Wooldridge J. M. (1996). Econometric methods for fractional response variables with an application to 401(k) plan participation rates. Journal of Applied Econometrics, 11(6), 619-632. 
Papke, L. E., \& Wooldridge J. M. (2008). Panel data methods for fractional response variables with an application to test pass rates. Journal of Econometrics, 145(1-2), 121-133.

Prud'homme, R. (1995). The dangers of decentralization. The World Bank Research Observer, 10(2), 201-220.

Riker, W. H. (1964). Federalism: Origin, operation, significance. Boston: Little, Brown \& Company.

Rodden, J. (2004). Comparative federalism and decentralization: On meaning and measurement. Comparative Politics, 36(4), 481-500.

Rodden, J., \& Wibbels, E. (2002). Beyond the fiction of federalism: Macroeconomic management in multitiered systems. World Politics, 54(4), 494-531.

Rodrik, D. (1998). Why do more open economies have bigger governments? Journal of Political Economy, 106(5), 997-1032.

Sato, M. (2007). The political economy of interregional grants. In R. W. Boadway, \& A. Shah (Eds.), Intergovernmental fiscal transfers: Principles and practices (pp. 173-201). Washington, D.C.: World Bank. 
Schaffer, M. E., 2005. XTIVREG2: Stata Module to Perform Extended IV/2SLS, GMM and AC/HAC, LIML and k-class Regression for Panel Data Models. Statistical Software Components S456501, revised edition. Boston College Department of Economics, Chestnut Hill, MA.

Shah, A. (2007). A Practitioner's guide to intergovernmental fiscal transfers. In R. W. Boadway, \& A. Shah (Eds.), Intergovernmental fiscal transfers: Principles and practices (pp. 1-53). Washington, D.C.: World Bank.

State Council, the Chinese Central Government. (2002). Forwarding the document of Ministry of Finance on perfecting sub-provincial fiscal management (in Chinese, No.26), internal document.

Stock, J. H., \& Yogo, M. (2005). Testing for weak instruments in linear IV regression. In D. W. K. Andrews, T. J. Rothenberg \& J. H. Stock (Eds.), Identification and inference for econometric models: Essays in honor of Thomas Rothenburg (pp. 80-108). Cambridge; New York: Cambridge University Press.

Stegarescu, D. (2005). Public sector decentralization: Measurement concepts and recent international trends. Fiscal Studies, 26(3), 301-333. 
Stegarescu, D. (2009). The effects of economic and political integration on fiscal decentralization: Evidence from OECD countries. Canadian Journal of Economics, 42(2), 694-718.

Tanzi, V. (2000). On fiscal federalism: Issues to worry about. World Bank Conference on Fiscal Decentralisation, Washington, DC.

Tiebout, C. (1956). A pure theory of local expenditures. Journal of Political Economy, (64), 416-424.

Uchimura, H., \& Jutting, J. P. (2009). Fiscal decentralization, Chinese style: Good for health outcomes? World Development, 37(12), 1926-1934.

Wheare, K. C. (1964). Federal government. London: Oxford University Press.

Wooldridge, J. M. (2006). Introductory econometrics: A modern approach (3rd ed.). Ohio: Thomson/South-Western.

World Bank. (2002). China: National development and subnational finance, a review of provincial expenditures. Washington: World Bank.

World Bank. (2007). China improving rural public finance for the harmonious society. Washington, D.C.: World Bank. 
Wu, A. M. (2010). Civil service pay arrears at county level in China: Causes and implications. (Unpublished Ph.D. dissertation). City University of Hong Kong.

Wu, A. M., \& Lin, M. (2012). Determinants of government size: Evidence from China. Public Choice. 151(1-2), 255-270.

Yeung, R. (2009). The effects of fiscal decentralization on the size of government: A meta-analysis. Public Budgeting and Finance, 29(4), 1-23.

Zhang, G. (2009). A primary research on fiscal decentralization across provinces in China since the 1994 fiscal reform. Journal of Public Administration (in Chinese), $1,133-158$. 
Table 1. Measurement and data source

\begin{tabular}{|c|c|c|}
\hline Variable & Measurement & Data source \\
\hline $\begin{array}{l}\text { Fiscal } \\
\text { decentralization }\end{array}$ & $\begin{array}{l}\text { Sub-provincial } \\
\text { expenditure as a share } \\
\text { of total provincial and } \\
\text { sub-provincial } \\
\text { expenditure }\end{array}$ & $\begin{array}{l}\text { Compendium of Fiscal } \\
\text { Statistics for All Prefectures, } \\
\text { Cities, and Counties } \\
\text { (Quanguo dishixian caizheng } \\
\text { tongji ziliao) }\end{array}$ \\
\hline $\begin{array}{l}\text { Transfer } \\
\text { dependency }\end{array}$ & $\begin{array}{l}\text { Central fiscal transfer } \\
\text { as a share of total } \\
\text { provincial and } \\
\text { sub-provincial } \\
\text { expenditure }\end{array}$ & $\begin{array}{l}\text { Finance Yearbook of China } \\
\text { (zhongguo caizheng } \\
\text { nianjian) }\end{array}$ \\
\hline $\begin{array}{l}\text { Economic } \\
\text { development }\end{array}$ & $\begin{array}{l}\text { Real GDP per capita (in } \\
\text { natural logarithm) }\end{array}$ & $\begin{array}{l}\text { China compendium of } \\
\text { statistics } 1949-2008\end{array}$ \\
\hline $\begin{array}{l}\text { Population } \\
\text { density }\end{array}$ & $\begin{array}{l}\text { Inhabitant per sq. km } \\
\text { (in natural logarithm) }\end{array}$ & $\begin{array}{l}\text { China compendium of } \\
\text { statistics } 1949-2008\end{array}$ \\
\hline $\begin{array}{l}\text { Share of FDI in } \\
\text { GDP }\end{array}$ & FDI as a share of GDP & $\begin{array}{l}\text { China compendium of } \\
\text { statistics } 1949-2008\end{array}$ \\
\hline $\begin{array}{l}\text { Share of trade in } \\
\text { GDP }\end{array}$ & $\begin{array}{l}\text { Sum of imports and } \\
\text { exports as a share of } \\
\text { GDP }\end{array}$ & $\begin{array}{l}\text { China compendium of } \\
\text { statistics } 1949-2008\end{array}$ \\
\hline $\begin{array}{l}\text { Share of SOE } \\
\text { employment in } \\
\text { population }\end{array}$ & $\begin{array}{l}\text { SOE employees as a } \\
\text { share of the total } \\
\text { population }\end{array}$ & $\begin{array}{l}\text { China compendium of } \\
\text { statistics } 1949-2008\end{array}$ \\
\hline $\begin{array}{l}\text { Share of } \\
\text { secondary sector } \\
\text { in GDP }\end{array}$ & $\begin{array}{l}\text { The output of the } \\
\text { secondary sector as a } \\
\text { share of GDP }\end{array}$ & $\begin{array}{l}\text { China compendium of } \\
\text { statistics } 1949-2008\end{array}$ \\
\hline
\end{tabular}


Table 2. Descriptive statistics (1995-2006)

\begin{tabular}{lccccc}
\hline Variable & Mean & Std. Dev. & Min & \multicolumn{2}{c}{ Max Observations } \\
\hline Fiscal decentralization & 0.71 & 0.10 & 0.44 & 0.89 & 360 \\
Transfer dependency & 0.51 & 0.14 & 0.18 & 0.93 & 359 \\
Economic development & 8.18 & 0.49 & 7.32 & 9.65 & 360 \\
Population density & 5.34 & 1.23 & 1.93 & 7.73 & 360 \\
Share of FDI in GDP & 0.04 & 0.04 & 0.00 & 0.24 & 360 \\
Share of Trade in GDP & 0.27 & 0.34 & 0.03 & 1.75 & 360 \\
Share of SOE & & & & & 360 \\
employment in population & 0.08 & 0.04 & 0.03 & 0.29 & 360 \\
Share of Secondary Sector & & & & & \\
in GDP & 0.45 & 0.07 & 0.20 & 0.62 & \\
\hline
\end{tabular}

Note: Economic development and population density are in logarithms 
Table 3. Determinants of fiscal decentralization (1995-2006)

\begin{tabular}{|c|c|c|c|c|c|c|}
\hline \multirow{3}{*}{$\begin{array}{l}\text { Model: } \\
\text { Estimation method: }\end{array}$} & \multicolumn{4}{|l|}{ Linear } & \multirow{2}{*}{\multicolumn{2}{|c|}{$\frac{\text { Fractional probit }}{\text { Pooled QMLE }}$}} \\
\hline & \multicolumn{2}{|c|}{ Fixed effects } & \multicolumn{2}{|l|}{ 2SLS } & & \\
\hline & 1 & 2 & 3 & 4 & 5 & 6 \\
\hline Transfer dependency & $\begin{array}{l}-0.164 * * * \\
(0.037)\end{array}$ & $\begin{array}{l}-0.156^{* * *} \\
(0.033)\end{array}$ & $\begin{array}{l}-0.178 * * * \\
(0.032)\end{array}$ & $\begin{array}{l}-0.169 * * * \\
(0.031)\end{array}$ & $\begin{array}{l}-0.158 * * * \\
(0.058)\end{array}$ & $\begin{array}{l}-0.159 * * * \\
(0.058)\end{array}$ \\
\hline Economic development & $\begin{array}{l}0.064 \\
(0.073)\end{array}$ & $\begin{array}{l}0.071 \\
(0.082)\end{array}$ & $\begin{array}{l}-0.062 \\
(0.101)\end{array}$ & $\begin{array}{l}-0.062 \\
(0.121)\end{array}$ & $\begin{array}{l}-0.075 \\
(0.097)\end{array}$ & $\begin{array}{l}-0.092 \\
(0.124)\end{array}$ \\
\hline Population density & $\begin{array}{l}-0.320 * * * \\
(0.109)\end{array}$ & $\begin{array}{l}-0.316^{* * *} \\
(0.107)\end{array}$ & $\begin{array}{l}-0.223 * * \\
(0.100)\end{array}$ & $\begin{array}{l}-0.230 * * \\
(0.101)\end{array}$ & $\begin{array}{l}-0.174 \\
(0.185)\end{array}$ & $\begin{array}{l}-0.163 \\
(0.197)\end{array}$ \\
\hline Share of FDI in GDP & $\begin{array}{l}-0.279 * * \\
(0.116)\end{array}$ & $\begin{array}{l}-0.270^{* *} \\
(0.126)\end{array}$ & $\begin{array}{l}-0.221 * * \\
(0.092)\end{array}$ & $\begin{array}{l}-0.203 * \\
(0.103)\end{array}$ & $\begin{array}{l}-0.174 \\
(0.204)\end{array}$ & $\begin{array}{l}-0.165 \\
(0.209)\end{array}$ \\
\hline Share of Trade in GDP & $\begin{array}{l}0.035 \\
(0.027)\end{array}$ & $\begin{array}{l}0.039 \\
(0.031)\end{array}$ & $\begin{array}{l}0.028 \\
(0.022)\end{array}$ & $\begin{array}{l}0.028 \\
(0.026)\end{array}$ & $\begin{array}{l}0.035 \\
(0.039)\end{array}$ & $\begin{array}{l}0.034 \\
(0.039)\end{array}$ \\
\hline Share of SOE employment in population & & $\begin{array}{l}0.074 \\
(0.194)\end{array}$ & & $\begin{array}{l}-0.019 \\
(0.185)\end{array}$ & $\begin{array}{l}0.016 \\
(0.313)\end{array}$ & $\begin{array}{l}0.004 \\
(0.316)\end{array}$ \\
\hline Share of Secondary Sector in GDP & & $\begin{array}{l}-0.085 \\
(0.066)\end{array}$ & & $\begin{array}{l}-0.074 \\
(0.066)\end{array}$ & $\begin{array}{l}-0.065 \\
(0.104)\end{array}$ & $\begin{array}{l}-0.063 \\
(0.105)\end{array}$ \\
\hline R-squared & 0.52 & 0.53 & 0.51 & 0.51 & & \\
\hline $\mathrm{N}$ & 359 & 359 & 359 & 359 & 359 & 359 \\
\hline
\end{tabular}


Notes: 1$) * * * \mathrm{p}<0.01, * * \mathrm{p}<0.05, * \mathrm{p}<0.1$.

2) Economic development and population density are in logarithms.

3) In models 3-4 and 6, the economic development variable is treated as endogenous.

4) The standard errors, in parentheses, in the linear models are robust HAC standard errors. Those in fractional probit models were obtained using 1,000 bootstrap replications.

5) All models contain year dummies for 1996 through 2006.

6) The APEs are reported for fractional probit models; those for the time averages of the explanatory variables are not included in the table. 
1 Mogues and Benin (2012) in a study of local public finance in Ghana find that central grants tend to discourage the generation of local own revenue.

${ }^{2}$ In addition, studies on flypaper effect indicate that an increase in lump-sum intergovernmental grants stimulates much more spending by lower-level governments than an equivalent increase in individual disposable incomes (Bailey and Connolly, 1998).

${ }^{3}$ Much of the literature has so far used subnational expenditure or revenue as a share of national expenditure or revenue to measure fiscal decentralization. However, many point out that budgetary shares are imperfect indicators for measuring the real fiscal autonomy of local governments (Ebel \& Yilmaz, 2003; Uchimura \& Jütting, 2009). Non-fiscal measures therefore appear in some recent literature (Ebel \& Yilmaz, 2003).

${ }^{4}$ According to Greene (2000), measurement error of the dependent variable can be absorbed in the regression error term and thus be ignored, as long as the independent variable is measured properly in the model (Stegarescu, 2005).

5 The central government in China channels fiscal transfers to provincial governments, while the latter allocates them to lower levels of government. It does not deal with sub-provincial governments directly with respect to fiscal issues.

${ }^{6}$ As indicated below, we adopt fixed effects models for the empirical analysis. Thus we cannot include both population size and population density in the estimation, as the denominator for the calculation of population density, i.e. provincial land area, is time-invariant.

7 Several studies document that fiscal decentralization has an impact on economic development. For example, Lin and Liu (2000) report that fiscal decentralization contributes positively to economic development in China.

${ }^{8}$ The results of the likelihood-ratio test for heteroskedasticity $($ LR chi2 $(29)=184.49$, Prob $>$ chi2 $=$ $0.00)$ and the Wooldridge test for autocorrelation $(F(1,29)=66.929$, Prob $>F=0.00)$ indicate the presence of heteroskedasticity and first-order autocorrelation.

9 The model was estimated with the xtivreg2 procedure in STATA (Schaffer, 2005). The weak instrument test compares the Kleibergen-Paap rk statistic to critical values established by Stock and Yogo (2005). While this comparison is not technically correct due to non-i.i.d. errors, Baum, Schaffer, 
and Stillman (2007) argue that this is a reasonable approximation. In the model, the Kleibergen-Paap rk statistic is well above any critical values established by Stock and Yogo (2005). In addition, the Sargan statistic in the over identification test indicates that all instruments are valid instruments, i.e., uncorrelated with the error term, and that the excluded instruments are correctly excluded from the model (Hayashi, 2000).

${ }^{10}$ When we dropped the four centrally direct-controlled municipalities (Beijing, Shanghai, Tianjin and Chongqing) from the analysis, the major results remained unchanged.

${ }^{11}$ The province-managing-county (shengguanxian) reform implemented in recent years has intended to mitigate the transmission problem of central and provincial grants at the prefectural level, which is beyond the scope of this research.

12 Martinez-Vazquez and Qiao (2011) also advocate horizontal accountability mechanisms to be put in place wherein residents can have a say over public finance in China. 